\title{
Linguistic Variation Among Southern and Northern Jordanian Dialects
}

\author{
التباين اللغوي بين اللهجة الجنوبية و اللهجة الشمالية في الأردن \\ Tamadur Sulayman Al-Shamayleh
}

Jordan / 0772072724

tamadershamileh@yahoo.com

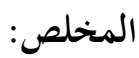

لكل بجتمع خصائصه اللغوية التي تعكس العديد من العوامل الاجتماعية , الثقافية

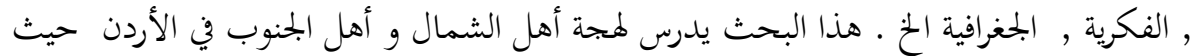
تم اظهار العديد من الاختلافات الصوتية والمورفولوجية و غيرها علما أن معظم الدراسات السابقة

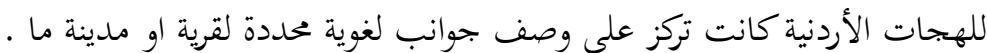

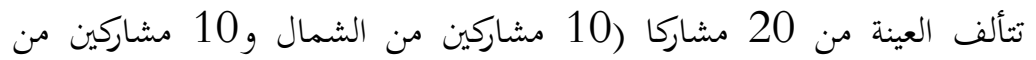

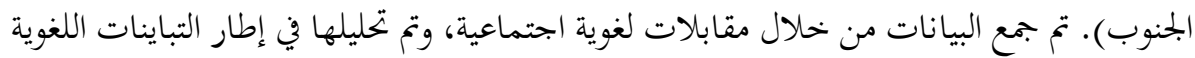
.Paradigm

و أظهرت النتائج أن هناك اختلافات صوتية ومورفولوجية كبيرة بين لهجة أهل الشمال

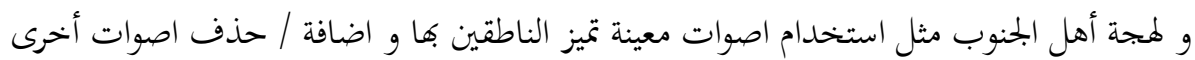

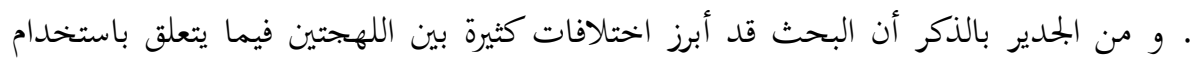
الضمائر و اللواحق و طرق الاستفهام و النفي عداك عن الاختلافات بالتراكيب و التعابير المستخدمة . الكلمات الرئيسية: تباين اللغة، الاختلاف الصوتي والمورفولوجي، اللواحق.

\section{Abstract:}

Each community has its linguistic characteristics due to social, structural, or geographical factors. This research looks at Jordan; it explores language variation in the speech of nonstandard Jordanian Arabic in the southern and northern 
regions in Jordan. Many phonological and morphological variations are examined.

The sample consists of 20 inhabitants 10 participants from the north and 10 participants from the south). The data were collected through sociolinguistic interviews, and they have been analyzed within the framework of the VariationistParadigm.

The results reveal that there are considerable phonological and morphological variations between the southern and northern dialects.

Keywords: language variation, phonological and morphological variation, nonstandard Jordanian Arabic.

\section{Introduction:}

This is a sociolinguistic study based on data gathered by audio-recorded interviews to study the local Jordanian dialects (northern and southern). Consequently, it is necessary to present briefly a profile of the Hashemite Kingdom of Jordan regionally, linguistically, and socially.

The area of the Hashemite Kingdom of Jordan is 89,318 square kilometers. It is located in the southwest of Asia bordering; Syria to the north, Saudi Arabia to the south and the southeast, Iraq to the east, and Palestine to the west. It is considered the heart of the Arab World depending on its core location.

Administratively, Jordan is divided into three main regions. The northern region includes four governorates (Irbid, Mafraq, Ajloun, and Jerash). The population of this region is about 591,000. The central region includes four governorates (Amman, Balqa, Zarqa, and Madaba)with a 
population of $3,595,200$. The third region is the southern region which also includes four governorates (Karak, Ma'an, Tafilah, and Aqaba). Its population is 536,800. Each governorate is divided into many districts which encompass many villages.

In this study, my main interest is to focus on two regions only; northern and southern. The central region has been excluded for some reasons which will be explained hereafter. It is worth mentioning that many preceding studies focus on studying certain linguistic varieties in some towns or villages in Jordan. However, this study is the first one that highlights the major linguistic variations among the northern and southern regions. Linguistically, the whole speech community in the Arab World is a diglossic one. Within any diglossic context, there will be two main varieties; low and high (Ferguson, 1959; Haeri, 1987; Omari \& Herk, 2016). Each variety is mainly used in certain sociolinguistic settings. The High variety is called Classical/ Standard Arabic; the variety of the Holy Quran and traditional Arabic literature. Whereas the Low variety (or what is called Modern Standard Arabic) is widely used in various formal settings such as formal speeches, news, conferences, the language of publication, and academic institutions (Khalil, 2010).

Arab sociolinguists divided Jordanian Arabic into three main spoken dialects. This division is based on social, economic, and geographical boundaries in the country (AbdEljawad, 1986; Alkhateeb, 1988, Al-Sughayer, 1990; Sakarna, 2005). They are the urban dialect, the rural dialect, and the Bedouin dialect. The urban dialect is spoken in the main cities like Amman and Zarqa. The rural dialect is widely 
used in the suburbs of the main cities as well as in villages. However, the Bedouin dialect is widely spread in the southern and eastern regions of Jordan. It is true to say that the lifestyle in Jordan also plays a role in dividing the Jordanian dialects in this way. Lifestyle is mainly linked with the tribe and the surrounding environment that we belong to. It is seen as a marker of our social allegiance, solidarity, and group identity. The main tool to express our social allegiance is by keep using our dialects. Thus, a rural environment has different lifestyles compared to an urban or Bedouin lifestyle.

Dialects in Jordan are experiencing ongoing change as a result of many factors. Young Jordanians have started imitating and adopting two regional dialects of the Middle East, namely Lebanese and Syrians, as a result of the effect of media. Saidat (2018) studied the influence of these two regional dialects as a linguistic invasion of Jordanian Arabic. In the past, Jordanian $\mathrm{TV}$ presenters, as well as radio broadcasters, are from Syria and Lebanon. Many young Jordanians, especially females, look at these dialects as a source of power and prestige. Moreover, their view of their original varieties also has been changed. For them, they look to their varieties as they reflect harshness and Bedouinisim! This cultural invasion is the result of mass media.

Another factor has to do with the interplay between Jordanians and Palestinians as a result of the immigration of a large number of Palestinians to Jordan. This has a great influence on the sociolinguistic situation in Jordan. A large number of refugees have mainly settled in the urban centers. As a result, many indigenous Jordanian varieties have been affected by slightly different accents. In addition to that, 
Jordanian dialects have been influenced by the increasing contact with non-Arabic languages such as Turkish, Kurdish, Circassian ...etc (Abu Ain, 2016).

In light of all previous factors, the center region (Amman, Zarqa, Balqa, and Madaba)has been excluded in this study. This region is largely influenced by the cultural invasion made by weak Jordanian media and with immigration; a large number of immigrants whether from Middle eastern countries or foreign countries have settled in this region. Consequently, this creates a rapid change towards " urbanization". Such cultural diversity in the central region harms our original local varieties. It is obvious that within this region (mainly Amman and Zarqa) there is no native traditional dialect; their linguistic situation was largely characterized by an unsystematic mixture of features from different dialects and languages. Consequently, the participants in this study are indigenous purely Jordanians from only the southern and northern regions.

\section{Review of related literature:}

In the Hashemite Kingdom of Jordan, several researchers are deeply interested in studying the Jordanian dialects. Some are concerned with studying the presence or absence of specific phonological, lexical, or grammatical features in certain dialects. Others are interested in describing varieties spoken in certain places. Still, others make comparisons between certain dialects to show the role played by certain social, cultural, and regional aspects. Of course, dialects keep changing over time. Consequently, many researchers are interested in studying dialect in contact, dialect change, and code-switching. 
Altoma (1969) discussed the use of both Standard Arabic and Colloquial Arabic. Accordingly, the use of Standard Arabic is considered more prestigious than Colloquial Arabic in which he states, "Despite its use as the dominant medium of the spoken word in conversation and various cultures or artistic contexts such as songs, stage, and movies, the Colloquial lacks the prestige enjoyed by the Classical and is looked upon, often with a considerable degree of contempt, as a stigma of illiteracy and ignorance." (p.3)

Abd-el-Jawwad(1986); Al-Khateeb (1988); AlSughyer (1990) and Sakarna (2005)state that Jordanian Arabic is a multidialectal variety since there are three local Jordanian varieties: rural (commonly used in villages and towns), urban (commonly used in major urban centers of the country, such as Amman and Irbid), and the Bedouin dialects (commonly used in the eastern and southern parts of the country). According to Miller (2007), " linguistically, the categories of Bedouin, rural and urban dialects are still used by most linguists on the bases of the presence/ absence of a set of features rather than by reference to geographical region or lifestyle." (p.9) As a result, these linguistic representations echo some of the local identity discourses. Referring to " origin" or " family" is important in self-affiliation discourse.

According to Zuraiq and Abu-Joudeh (2013), there are four main regional Jordanian dialects. They state " Although it is not possible to draw neat boundaries within Jordanian Arabic, it consists of four regional dialects: Ammani Dialect (AD) is spoken in the capital city by almost two million people who are dialectically analogous to 
Palestinian Arabic, RUND is spoken by another two million people who are considered native village dwellers especially in the northern part of the country, GD ( Gorani is a term used to refer to people who live in the Jordan Valley which forms the border between Jordan to the east and the West Bank to the west) is spoken by farmers, almost one million, in the Jordan Valley are, and BD is spoken by nomadic tribes, one million in the desert area from the northern to the southern side." (p.73)

Mohammad \&Al-Harahsheh (2014) also investigate the dialects in Jordan. They state that there are four dialects in Jordan; Standard Arabic which is the official language; it is generally used in media as well as official governmental departments. The second dialect is the urbanized dialect which is used by most people in city centers. It is highly prestigious, so the young females use it whatever their regions are. The third one is the rural dialect which is widely used in rural and agricultural areas. It is unlike urban dialect not only in pronunciation but also in vocabulary and grammar. The fourth dialect is the Bedouin dialect which is used in the Eastern and parts of the southern regions of the kingdom.

Irshied (1984) examined a Bedouin Jordanian dialect (Bani Hassan Arabic; BHA). He explained the distribution of / $\mathrm{u} /$ and / $\mathrm{i} / \mathrm{in}$ BHA. He found that BHA curtailed the use of / $\mathrm{u}$ / (the short high back vowel) in comparison with classical Arabic. In BHA, / $\mathrm{u} /$ occurs in just CVCC nominals and followed by labial / $\mathrm{m} /$ or / b/ as in kumm 'sleeve' and $h u b b$ 'love'. However, BHA changes Classical Arabic $\mathrm{CuCC}$ nouns into $\mathrm{CiCC}$ when the vowel is not followed by a 
labial for example kill 'all' and širb 'drinking', from the Classical Arabic kull and šurb.

Abd-el-Jawad and Awwad (1989) investigated the Arabic interdentals in Jordan as well as other cities in the Arab World. The result of their study shows that male speakers in Jordan pronounced the interdentals in their localized forms more than women. Although the localized forms of interdentals coincide with the standard pronunciation in Standard Arabic, they are seen and treated as old and less prestigious. For example, many females pronounce the localized formmatalan ' for example' as matalan or masalan.

Sakarna (2005) investigated the main differences between the Bedouin and rural Jordanian dialects. He demonstrated that these dialects cannot be classified as one dialectal group. His study focuses on lexical and phonological variations between rural dialect $(\mathrm{RD})$ and the Bedouin dialect (mainly two Bedouin dialects: BaniSahar and Bani Hassan). The data shown emphasize the lexical differences between RD and BD (BaniSahar and Bani Hassan). Moreover, this study shows how RD has a special type of epenthesis. Moreover, the use of trisyllabic elision while raising is restricted to Bani Hassan. The results of the above study demonstrate that $\mathrm{RD}$ and Bedouin dialects are different where the Bedouin dialects do not accommodate the urban dialect.

Al-Masaeed (2012) investigated the effect of the urban variant $[\mathrm{k}]$ on the rural area dialect within the superlocal environment "Irbid". Al-Masaeed claims that young rural speakers in Irbid prefer the use of super local variant [k] 
instead of the localized variant [t $\mathrm{t}$ ]during their speech. Unlike the older speakers who prefer the use of the localized variant $[\mathrm{t}]]$ in their speech. For example, older speakers say tfӨeer

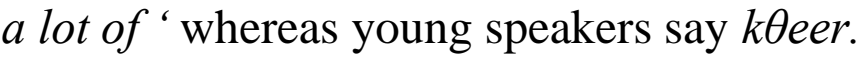

Abu Ain (2016) conducted a study that examines variation in the use of two Horani traditional features in the dialect of Saham (a north most village in Jordan). The study's variables are the alternation between / $\mathrm{u} /$ and / $/$ / / $\mathrm{u} /$ is the traditional local Horani realization while / $\mathrm{i} /$ is a characteristic of the koineised (creating a new dialect as a result of mobility and dialect contact) modern and city Jordanian dialects) and the use of dark / 1 / which is a stereotypical feature of the traditional local dialect. These variables are studied concerning three linguistic factors (position in syllable, preceding, and following environments). The result of the study shows considerable variation and change in progress in the use of both variables, constrained by linguistic and social factors. The innovative variant [ i] was found to be favored in the environment whenever it is preceded or followed by coronal sounds. Moreover, the traditional variant / 1/ (dark / 1/) was favored when preceded or followed by a back vowel. The result of this study highlights the changes that local communities have experienced as a result of urbanization as well as the increasing access to the target features through contact with outside communities.

Omari and Herk (2016) investigated the influence of linguistic and social forces on interdental variations in JA using GoldVarb (a statistical application that could be used for sociolinguistic analysis purposes) application. The 
sample of the study consists of 9 young speakers. There are three variables which are analyzed / $\theta$, ð,ð ${ }^{\varsigma}$ (Voiced velarized/emphatic interdental fricative)/. The researchers also examine sociolinguistic factors include the immediate phonological context, stress, word class, syllable and word position, frequency, sex of speakers, and urbanization. The result of this study shows that stopping is favored by the urban and semi-urban female speakers, while the stridents are favored among the urban group. / $\theta$ / can be realized as $[\theta]$, [ $\mathrm{t}$ ], and [ s ] ; / ð / could be realized as [ð], [ d ], and [z ] ; and / $\chi^{\varsigma} /$ could be realized as $\left[\delta^{\varsigma}\right],\left[d^{\complement}\right]$ (Voiced velarized/emphatic dento-alveolar plosive $),\left[\mathrm{z}^{\mathrm{h}}\right]$. The stops and sibilants are socially valued as markers of urban modernity among Jordanian speakers. Unlike the interdental variants which are markers of rural and Bedouin speakers.

Alrabab'ah (2018) investigated the effect of phonological and social factors (age, education, word style, and phonological environment) on[t] production. The results did not reveal any significant difference in the use of the marked variant [ $\mathrm{t}]$ ] which is an allophone of / $\mathrm{k} /$ among rural Jordanian Arabic in suburban Irbid. The sample of the study consists of 24 speakers of rural Jordanian Arabic in Irbid. Data were collected through recording as well as a distributional questionnaire. The results did not reveal any significant difference among the three different age groups or educational level (educated and uneducated). However, there was a slight difference in style since the speakers tended to use the super local form $/ \mathrm{k} /$ in favor of the localized variant [t $\left.\int\right]$ in naming pictures test versus spontaneous speech or dialogue. 


\section{Methodology of the study:}

In any sociolinguistic studies, the sample has to be selected carefully to get a high level of accuracy of the results. Therefore, in this study the sample has been chosen from both the northern and southern regions in Jordan to highlight the main differences in their speech production. It consists of 20 informants who are originally Jordanian ; therefore, they use one of the Jordanian dialects. (10) informants are from the north region and (10) are from the south region. It is worth noting that the participants were chosen from even different places with the two recommended regions. They vary in their age, gender, educational background and occupation. Studying this sample is based on giving them the chance to talk freely about any topic(s) they want.

Many instruments and procedures have been applied; qualitative interviews and Milroy's a friend - of $-\mathrm{a}$ friend procedure. The participants were encouraged to speak naturally and openly using their original dialects without embarrassment since the participants knew the assistants (my friends) in advance. Even though, my assistants did not tell them previously that their speech was recorded to get more reliable and natural data. After the recording process had completed, I and my assistants told them about the recording. We asked them the permission to analyze their speech, and we assured them that the recording will be used only for academic purposes. It was taken into account while choosing the participants from both regions to have a relatively similar 
demographic variables such as age, gender, and the educational level .

\section{Results and findings:}

Although there are many sociolinguistic studies about the Jordanian dialects, none of them deals with the linguistic differences between the northern (hereafter ND) and southern(hereafter SD) Jordanian dialects. Most of these studies investigate certain linguistic aspects of a specific place or an area or even a tribe. Abdel-Jawad (1981) investigated Amman, Al-Khatib (1988) on Irbid, Al-Tamimi (2001) on Irbid, El-Salman (2003) on Palestinians in Kerak, Al-Wer $(2002,2003,2007)$ on the formation of the dialect of Amman, Al-Hawamdeh (2016) on Sūf, and Abu Ain (2016) on Saham. Others try to highlight the linguistic variations of the Jordanian dialects on the bases of dividing the Jordanian dialects into urban, rural and Bedouin (Al-Sughayer (1990), Abd-el-Jawad (1981) and Al-Khatib (1988). However, this study suggests another suitable division (ND and SD) based on the absence and the presence of certain linguistic features. This division could be useful because Jordan is a tribal country and dividing its dialects into urban, rural and Bedouin depend on their place of living and their lifestyle far away from their tribal solidarity and their social identity ! Indigenous Jordanians who belong to the same tribe almost speak exactly alike whether they live in a rural or an urban area. There are many Bedouins (for example) who live in urban cities but they speak Bedouin! It is noted that some researchers analyzed the speech of immigrants who live in Jordan for a period of time as they are Jordanians! The loyalty and solidarity to our tribe and social networks prevent us 
unintentionally to change easily our dialects. In many cases, it is easily to distinguish whether a person is from the north or the south depending only on his $\backslash$ her dialect.

In order to study and examine these linguistic variation among the two recommended dialects (ND and SD), audiorecorded interviews of 14 informants, who are originally purely Jordanian, are collected and analyzed. Analyzing their speech reveals many salient features.

One of these features is the use of [k] and [t] variants. The [k] variant is used widely in the SD whereas the variant [g] is used instead in the ND. The use of [t] could be a result of dialect contact with some areas of southern Syria. AlMasaeed (2012) claimed that the [t] variant of $/ \mathrm{k} /$ is a prevalent and distinguishing sound in the northern region of Jordan as well as some areas of Southern Syria. The phoneme/k/ is realized as an affricated in many lexical items in the ND while the same lexical items are not at all affricated

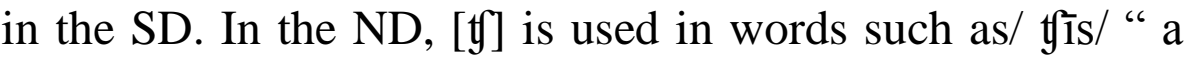
bag", / t yêf/ " how", / di ty/ " a roaster" and / tyafan/ "a shroud". However these words are pronounced as/ kīs/, /kēf/, /dī k/ and $/ \mathrm{kafan} /$ in the SD.

$[\mathfrak{y}]$ is a salient and marked linguistic feature of the ND although it is not a common speech existent sound in Classical Arabic or Modern Standard Arabic. However, Alrabab'ah (2018) conducted a study regarding the use of [ $y$ ] in Irbid suburb. He firstly expected that $[\mathrm{k}]$ will replace the marked localized variant [t]. The results of the study revealed that the attitudes of the speakers, whether they are educated or not, elderly or young, were highly positive towards the use of the variant [ty] which explain the reason behind the 
maintenance of $[\mathfrak{t}]$ variant up to now. Others, like Herin (2013), believed that although affrication is influenced by external sociolinguistic factors such as gender and age, it is linguistically conditioned; $[\mathfrak{t}]$ is realized as in the contiguity of front vowels but not of back vowels. It is used in words such as / tyêf/ but not with words containing back vowels such as / kum/ "sleeve". Also, it is widely used even among young age speakers because the youngsters were predicted to be the least exposed group to the supralocal dialect; therefore, they maintained the use of the variant[ty]. (Al-rabab'ah, 2018).

The use of the variant [t] is also associated with some morphological aspects such as the use of the second person possessive and object female pronouns within the ND. As table (1) shows:

\begin{tabular}{||c|c|c|c|c||}
\hline \hline & $\begin{array}{r}\text { Sg.fem. } \\
\text { possessive } \\
\text { pronouns }\end{array}$ & $\begin{array}{r}\text { Sg.fem.object } \\
\text { suffixes }\end{array}$ & $\begin{array}{r}\text { Sg.fem. } \\
\text { indirect } \\
\text { object }\end{array}$ & $\begin{array}{r}\text { Pl.fem. } \\
\text { indirect } \\
\text { object }\end{array}$ \\
\hline \hline SD & $-\mathrm{k}(\mathrm{i})$ & $-\mathrm{ik}(\mathrm{i})$ & - lik(i) & -ilkan \\
\hline ND & $-\mathrm{t} f$ & $-\mathrm{it} f$ & - litf & - iltfin \\
\hline
\end{tabular}

Thus, [t] could be associated with female pronouns among the northern region. This highlights one of the phonological -morphological aspects of this variant. It is not at all used with masculine pronouns as the following table (table 2) shows.

\section{Table (2)}




\begin{tabular}{|l|c|l|l|c||}
\hline \hline & $\begin{array}{r}\text { Sg.masc. } \\
\text { possessive } \\
\text { pronouns }\end{array}$ & $\begin{array}{l}\text { Sg.masc } \\
\text { object suffixes }\end{array}$ & $\begin{array}{r}\text { Sg.masc. } \\
\text { indirect object } \\
\text { suffixes }\end{array}$ & \multicolumn{2}{|c|}{ Pl.masc. } \\
indirect r $\begin{array}{r}\text { object } \\
\text { suffixes }\end{array}$ \\
\hline \hline SD & $-\mathrm{k}$ & $-\mathrm{ak}$ & - laklillak & $-\mathrm{ilku}(\mathrm{m})$ \\
\hline ND & $-\mathrm{k}$ & $-\mathrm{ak}$ & - laklillak & \\
\hline
\end{tabular}

Using the variant [t] is not limited to certain parts of speech. It is used across different parts of speech (conjunctions, verbs, nouns, pronouns, interrogatives,...etc.) as the following table (table 3) shows that the two words ("if" and "was") have the same pronunciation in each dialect but they are used in different contexts to indicate different meanings and different functions:

Table (3)

\begin{tabular}{|c|c|c|}
\hline & /kān/ "if" & /kān/ "was" \\
\hline $\mathrm{SD}$ & /kān/ & /kān/ \\
\hline ND & /ţān/ & /tyān/ \\
\hline
\end{tabular}

Another distinguishing feature among the ND and SD has to do with the distribution of $/ \mathrm{u} /$ and $/ \mathrm{i} /$. The ND is characterized with a special type of epenthesis in which the back high vowel $/ \mathrm{u} /$ is inserted in different contexts unlike the $\mathrm{SD}$ in which the front high vowel/i/ is inserted in the same context respectively as it can be noted in table (4).

\section{Table (4)}




\begin{tabular}{|c|c|c|}
\hline $\begin{array}{c}\text { Modern } \\
\text { Standard Arabic } \\
\text { (MSA) }\end{array}$ & SD & ND \\
\hline /galb/" heart" & /galib/ & /galub/ \\
\hline /furn/“oven” & / furin/ & /furun/ \\
\hline / fuyl/ "work" & / Juyil/ & / Juyul/ \\
\hline / dzamr/" embers" & /dzamir/ & /dzamur/ \\
\hline /gamh/ "wheat" & /gamih/ & /gamuh/ \\
\hline / xubz/"bread", & /xubiz/ & /xubuz/ \\
\hline
\end{tabular}

As it can be noted that all the given words have the same surface structure form (CVCC) in Modern Standard Arabic ( hereafter MSA) or " Fus ${ }^{\text {ha }}$ " dialect. In the ND, this underlying structure becomes $\mathrm{CVCuC}$ whereas in the SD it becomes CVCiC. Moreover, words which follow the structure CVCCa in MSA are also pronounces differently in the both recommended regions as it is stated in table (5).

Table (5)

\begin{tabular}{||l|l|l||}
\hline MSA & SD & ND \\
\hline \hline / luSbah/“"a toy” & lisbi & luSba \\
\hline /zubdah/“" butter” & zibdi $^{\text {h }}$ & zubda \\
\hline / dzubnah/ "cheese” & dzibni $^{\text {h }}$ & dzubna \\
\hline
\end{tabular}

Depending on the given examples, it is clearly seen that the ND is so close to MSA in this respect more than SD. Moreover, these examples highlight a general tendency in the 
ND regarding the deletion ofthe feminine suffix /-h/. This is a another case which demonstrates that fronting the back vowels is commonly spread within the SD.

Another case which demonstrates the high tendency of fronting the back vowels among people of the SD is in imperatives. In many imperatives, / $\mathrm{u} /$ is inserted instead of /i/ in the ND. Table (5) shows some examples in this regard.

Table (5)

\begin{tabular}{|c|c|}
\hline SD & ND \\
\hline $\begin{array}{l}\text { / } \lim / \text { "collect" } \\
\text { e.g / limhdūmak/ " collect } \\
\text { your clothes" }\end{array}$ & $\begin{array}{l}\text { /lum/“collect" } \\
\text { e.g / lumhdūmak/ " collect } \\
\text { your clothes" }\end{array}$ \\
\hline $\begin{array}{l}\text { /fik/“" untie" } \\
\text { e.g / fikalrabāt }{ }^{\mathrm{f}} / \text { " untie } \\
\text { your bootlace" }\end{array}$ & $\begin{array}{l}\text { /fuk/“" untie" } \\
\text { e.g / fukalrabāt } / \text { " untie } \\
\text { your bootlace" }\end{array}$ \\
\hline $\begin{array}{l}\text { / t }{ }^{\mathrm{S} i 1 /} \text { " look" } \\
\text { e.g / t"ilslēh/ "look at him" }\end{array}$ & $\begin{array}{l}\text { / t } \text { t }^{\mathrm{u}} / \text { " "look" } \\
\text { e.g / t } \mathrm{t}^{\mathrm{f}} \mathrm{ulclēh/"} \mathrm{look} \mathrm{at} \mathrm{him"}\end{array}$ \\
\hline $\begin{array}{l}\text { / sib/ "insult" } \\
\text { e.g / sib Slēh/" insult him!" }\end{array}$ & $\begin{array}{l}\text { / sub/ " insult" } \\
\text { e.g / sub Slēh/" insult him!" }\end{array}$ \\
\hline
\end{tabular}

Another difference has to do with the suffixes which are used to mark gender; most of the feminine nouns end with ($\mathrm{a}^{\mathrm{h}}$ ) in the SD. Instead, the suffix $(-\mathrm{a})$ is used in the ND. See table (6).

\section{Table (6)}




\begin{tabular}{|c|l|l|}
\hline MSA & SD & ND \\
\hline \hline $\begin{array}{l}\text { /lafhah/ " } \\
\text { scarf" }\end{array}$ & /lafhah/ & /lafha/ \\
\hline $\begin{array}{c}\text { / dzumSah/ " } \\
\text { Friday" }\end{array}$ & /dzumSah/ & /dzumSa/ \\
\hline $\begin{array}{l}\text { /malSaqah/ " } \\
\text { spoon" }\end{array}$ & /malSagah/ & /malSaga/ \\
\hline
\end{tabular}

As it can be seen that the SD in such cases is closer to MDA than the ND.Regarding pronouns, there are many differences. One of the pronoun lexical differences has to do with the first person singular masculine independent pronounsin which the southern form corresponds to MSA as it can be seen in the following table (table 7).

Table (7)

\begin{tabular}{|c|c|}
\hline & $\begin{array}{c}\text { First } \\
\text { personlSg.masc }\end{array}$ \\
\hline \hline SD & anā \\
\hline ND & anī \\
\hline
\end{tabular}

Also, there are another difference with the second person plural feminine independent pronouns as the following table (table 8) shows:

\begin{tabular}{|c|l|}
\hline & \multicolumn{1}{|c|}{ Second person pl. } \\
& $\begin{array}{l}\text { fem. Independent } \\
\text { pronouns }\end{array}$ \\
\hline \hline SD & intan \\
\hline ND & intin \\
\hline
\end{tabular}

In the preceding two tables, the use of /i/ with independent pronouns in the ND is obvious unlike the SD. 
Generally, the ND tremendously use dependent indirect object suffixes. The southern dialect use independent suffixes instead.

The following table (table 9) shows some examples:

\section{Table (9)}

\begin{tabular}{|c|c|c|c|}
\hline & & SD & ND \\
\hline & Sg.fem & $\begin{array}{l}\text { /-ilha/ } \\
\text { e.g/t } \mathrm{t}^{\mathrm{S}} \text { abaxit-ilha/ } \\
\text { "I cooked } \\
\text { for her" }\end{array}$ & $\begin{array}{l}\text { /-lha/ e.g / } \\
\text { t'abaxitlha/ } \\
\text { " I cooked } \\
\text { for her" }\end{array}$ \\
\hline Third & $\operatorname{masc}^{\text {Sg. }}$ & $\begin{array}{l}\text { /-tilu/e.g / } \\
\text { t'abaxit-ilu/ } \\
\text { " I cooked } \\
\text { for him" }\end{array}$ & $\begin{array}{l}\text { /-lu/ e.g / } \\
\text { t'abaxitilu/ } \\
\text { " I cooked } \\
\text { for him" }\end{array}$ \\
\hline $\begin{array}{l}\text { person } \\
\text { pronouns }\end{array}$ & Pl.fem & $\begin{array}{l}\text { /-ilhin/e.g } \\
\text { / t abaxit-ilhin/ } \\
\text { "I cooked } \\
\text { for them" }\end{array}$ & $\begin{array}{l}\text { /-lhin/ e.g / } \\
\mathrm{t}^{\mathrm{S} a b a x i t l h i n /} \\
\text { " I cooked } \\
\text { for them" }\end{array}$ \\
\hline & Pl.masc & $\begin{array}{l}\text { /-ilhum/ } \\
\text { e.g } / \mathrm{t}^{\mathrm{G}} \text { abaxit- } \\
\text { ilhum/ } \\
\text { " I cooked } \\
\text { for them" }\end{array}$ & $\begin{array}{l}\text { /-lhum/ e.g. } \\
\text { / t } \text { t abaxitlhum/ }^{\text {" I cooked }} \\
\text { for them" }\end{array}$ \\
\hline
\end{tabular}

The same is applicable in the second person pronouns as the following table (table 10) shows:

Table (10)

\begin{tabular}{|l||l|l|l|}
\hline \hline & & SD & ND \\
\hline
\end{tabular}




\begin{tabular}{|c|c|c|c|}
\hline \multirow[t]{4}{*}{ Second } & Sg.fem & $\begin{array}{l}\text { /-ilki/ e.g } \\
\text { /katabt-ilki/ } \\
\text { " I wrote } \\
\text { to you" }\end{array}$ & $\begin{array}{l}\text { /-litf/ e.g } \\
\text { /katabtlitf/ } \\
\text { " I wrote to } \\
\text { you" }\end{array}$ \\
\hline & Sg.masc & $\begin{array}{l}\text { /-ilak/ e.g } \\
\text { /katabt-ilak/ } \\
\text { "I I wrote } \\
\text { to you" }\end{array}$ & $\begin{array}{l}\text { /-lak/ e.g } \\
\text { /katabtlak/ } \\
\text { " I wrote to } \\
\text { you" }\end{array}$ \\
\hline & Pl.fem & $\begin{array}{l}\text { /-ilkan/ } \\
\text { e.g/katabt- } \\
\text { ilkan/ } \\
\text { “ I I wrote } \\
\text { to you”" }\end{array}$ & $\begin{array}{l}\text { /-1tgin/ e.g / } \\
\text { /katabtltin/ } \\
\text { " I wrote to } \\
\text { you" }\end{array}$ \\
\hline & Pl.masc & $\begin{array}{l}\text { /-ilku/ e.g } \\
\text { /katabt-ilku/ } \\
\text { "I I wrote } \\
\text { to you" }\end{array}$ & $\begin{array}{l}\text { /-lku/ e.g } \\
\text { //katabtlku/ } \\
\text { " I wrote to } \\
\text { you" }\end{array}$ \\
\hline
\end{tabular}

As it can be seen in the previous table, the vowel/i/ is inserted in all second person pronouns in the SD. These pronouns are pronounced as independent pronouns unlike the second person dependent pronouns in the ND. Accordingly, it could be suggested that the ND allows consonant clusters ( for example /btl/, /bltg/, /btlk/ in table (10)) more than the SD. The insertion of / $\mathrm{i} / \mathrm{decreases}$ the number of consonant cluster. This table also shows the use ofthe [t] variant with feminine pronouns.

Even with demonstrative pronouns, there are some differences between the ND and the SD (mainly in singular dexis) as it can be seen in table (11).

\section{Table (11)}




\begin{tabular}{|c|c|c|c|}
\hline & & SD & ND \\
\hline \multirow{3}{*}{ dexis $^{\text {Near }}$} & Sg.fem & \hāðil & \hay\ \\
\hline & Sg.masc & Thā $\delta^{\complement} a l$ & ไhā $\delta^{\varphi} \backslash$ \\
\hline & Pl. & 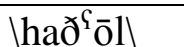 & ไhā $\delta^{\varsigma} \bar{o} l \backslash$ \\
\hline \multirow{3}{*}{ dexis $^{\text {Far }}$} & Sg.fem & \hað̄ikah\} $&{\text { \haðity }} \\
{\hline} &{\text { Sg.masc }} &{\text { ไhad }{ }^{\complement} \bar{a} a^{h} \backslash} &{\text { ไhad }{ }^{\complement} \bar{a} k \backslash} \\
{\hline} &{\text { Pl. }} &{\text { \hađ`̄ōlākl }} &{\text { ไhađ }{ }^{\complement} l a \bar{k} \backslash} \\
$\hline
\end{tabular}

There are also differences among the SD and the ND in the production of the past tense. Differences vary according to both gender and person as the following table (table 12) shows.

\section{Table (12)}

\begin{tabular}{|c|c|c|c|}
\hline \multirow{5}{*}{$\begin{array}{l}\text { First } \\
\text { person }\end{array}$} & & SD & ND \\
\hline & Sg.fem & $\begin{array}{l}\text { /laSibit/ “ I } \\
\text { play” }\end{array}$ & $\begin{array}{l}\text { /lGibit/ “ I } \\
\text { play” }\end{array}$ \\
\hline & Sg.masc & $\begin{array}{l}\text { /laSibit/ “ I } \\
\text { play” }\end{array}$ & $\begin{array}{l}\text { /lYibit/ “I } \\
\text { play” }\end{array}$ \\
\hline & Pl.fem & $\begin{array}{l}\text { /laGibna/ “ } \\
\text { we play” }\end{array}$ & $\begin{array}{l}\text { /lGibna/ } \\
\text { we play" }\end{array}$ \\
\hline & Pl.masc & $\begin{array}{l}\text { /laSibna/ “ } \\
\text { we play” }\end{array}$ & $\begin{array}{l}\text { /lYibna/ } \\
\text { we play" }\end{array}$ \\
\hline
\end{tabular}

Again, consonant clusters are also applied more in the ND. Vowel insertion in the SD is frequent. Moreover, in the ND the same structure (form) is used for singular feminine and masculine. It is also the same regarding the form used in the case of plural (both feminine and masculine) unlike the SD. See table (13)and table (14).

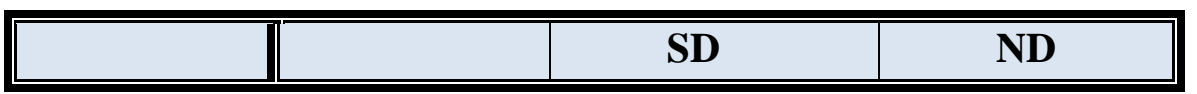




\begin{tabular}{|c|c|c|c|}
\hline \multirow[t]{4}{*}{$\begin{array}{l}\text { Second } \\
\text { person }\end{array}$} & Sg.fem & $\begin{array}{l}\text { /laYibt/ } \\
\text { you play” }\end{array}$ & $\begin{array}{l}\text { /lGibti// “ } \\
\text { you play” }\end{array}$ \\
\hline & Sg.masc & $\begin{array}{l}\text { /laSibit/ “ } \\
\text { you play” }\end{array}$ & $\begin{array}{l}\text { /lYibit/ “ } \\
\text { you play” }\end{array}$ \\
\hline & Pl.fem & $\begin{array}{l}\text { /laSabtan/ “" } \\
\text { you play” }\end{array}$ & $\begin{array}{l}\text { /lYibtin/ “ } \\
\text { you play” }\end{array}$ \\
\hline & Pl.masc & $\begin{array}{l}\text { /laSibtu/ " } \\
\text { you play" }\end{array}$ & $\begin{array}{l}\text { /lYibtu/ “ } \\
\text { you play” }\end{array}$ \\
\hline
\end{tabular}

Table (14)

\begin{tabular}{|c|c|c|c|}
\hline \multirow{5}{*}{$\begin{array}{l}\text { Third } \\
\text { person }\end{array}$} & & SD & ND \\
\hline & Sg.fem & $\begin{array}{l}\text { /laSbit/ } \\
\text { She played" }\end{array}$ & $\begin{array}{l}\text { /lisbat/ } \\
\text { She played" }\end{array}$ \\
\hline & Sg.masc & $\begin{array}{c}\text { /laSab/ } \\
\text { He played" }\end{array}$ & $\begin{array}{l}\text { /liSib/ " } \mathrm{He} \\
\text { played" }\end{array}$ \\
\hline & Pl.fem & $\begin{array}{l}\text { /laSaban/ } \\
\text { They played" }\end{array}$ & $\begin{array}{l}\text { /laSabin/ “ } \\
\text { They played”" }\end{array}$ \\
\hline & Pl.masc & $\begin{array}{r}\text { /laSabu/ } \\
\text { They played" }\end{array}$ & $\begin{array}{c}\text { /liSbu/ } \\
\text { They played" }\end{array}$ \\
\hline
\end{tabular}

Regarding interrogatives, there are some similarities and some differences between the two dialects. Both use interrogative pronouns such as /wēn/ "where?", /lawēn/ “ where to? " and / mata/ "when? ". However, there are many differences in the use of other interrogative pronouns as it is shown in the following table. (Table 15)

\begin{tabular}{|c|c|c|}
\hline $\begin{array}{l}\text { Interrogative } \\
\text { pronouns }\end{array}$ & SD & ND \\
\hline What? & 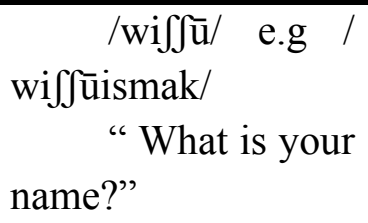 & 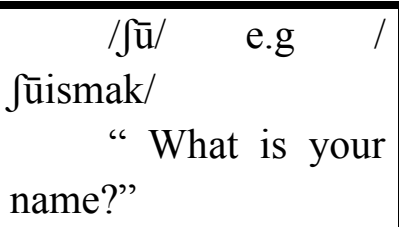 \\
\hline Which? & $\begin{array}{l}\text { /aj-ja/ e.g / aj- } \\
\text { jabāb/ }\end{array}$ & $\begin{array}{l}\text { / aj/ e.g /ajbāb/ } \\
\text { " which door?" }\end{array}$ \\
\hline
\end{tabular}




\begin{tabular}{|c|c|c|}
\hline & $\begin{array}{ll} & \text { which } \\
\text { door?" } & \end{array}$ & \\
\hline Why? & $\begin{array}{l}\text { /lawēel/ e.g / } \\
\text { lawēefhakēt/ } \\
\text { "Why did you } \\
\text { speak?" }\end{array}$ & $\begin{array}{l}\text { /lēfl e.g / } \\
\text { lēfhakēt/ }\end{array}$ \\
\hline When? & $\begin{array}{l}\text { /iktēh/ e.g / } \\
\text { iktēhwidaktrūh/ “" } \\
\text { When will you go?" }\end{array}$ & $\begin{array}{l}\quad / \text { amēt/ e.g / } \\
\text { amētbidattrūh/ } \\
\text { When will you go?” }\end{array}$ \\
\hline
\end{tabular}

\section{Conclusion:}

This study is conducted to highlight linguistic variation and change among the southern and northern Jordanian dialects. To do that, the speech of 10 participants from the south region and 10 participants from the north region has been recorded and analyzed.

The result of the study reveals that there are many phonological and morphological variations and differences among the participants of the two recommended regions. Some of these phonological and morphological variations go towards standardization but others towards urbanization. Still others are koineised. Further studies shall be conducted in this regard to show other linguistic variations.

\section{References:}


1. Abdel-Jawad, H. (1986). The Emergence of an Urban Dialect in the Jordanian Urban Centers. International Journal of the Sociology of Language, 16, 53-63.

2. Abedl-Jawad, H. (1981). Lexical and phonological variation in spoken Arabic in Amman ( Unpublished doctoral disseratation). University of Pennsylvania, Philadelphia PA, USA.

3. Abu Ain, N. (2016). A Sociolinguistic Study in Saham, Northern Jordan. PhD Diss., University of Essex.

4. AdbelJawad, H. \&Awwad, M. (1989). Reflexes of Classical Arabic Interdentals: A study in historical sociolinguistics. LinguistischeBerichte, 122, 259-282.

5. Al-Hawamdeh, A. (2016). A sociolinguistic investigation of two Hōrāni features in Sūf, Jordan. ( Unpublished doctoral dissertation). University of Essex, UK.

6. Al-Khatib, M. (1988). Sociolinguistic Change in an Expanding Urban Context: A Case Study of Irbid City. PhD Diss., University of Durham.

7. Al-Masaeed, N.R. (2012). The variant of "Ech" to "Ek" among residents of Irbid Governorate in light of gender and age. International Journal of English Linguistics, 2 (5), 60-64.

8. AlRabab'ah, S. (2018). Rural and Urban dialects in contact in Jordan: the case of [ $\left.\mathrm{t} \int\right]$ de-affrication 
in the rural dialect of Irbid suburbs ( MA thesis). University of Canterbury.

9. Al-Sughayer, K (1990). Aspects of Comparative Jordanian and Modern Standard Arabic. PhD Diss., Michigan State University.

10.Al-Tamimi, F. (2001). Phonetic and phonological variation in the speech of rural migrants in a Jordanian city (Unpublished doctoral dissertation). University of Leeds, UK.

11.Altoma, S.J.(1969). The problem of diglossia in Arabic. Cambridge: Harvard University Press.

12.Al-Wer, E. (2002). Jordanian and Palestinian dialects in contact: vowel raising in Amman. In M. Jones \& E. Esch (Eds.), Language change: the interplay of internal, external and extra-linguistic factors, 63-79. Berlin: Mouton de Gruyter. P. 251-265.

13.Al-Wer, E. (2003). New dialect formation: The focusing of-kum in Amman. In D. Britain and J.Cheshire (Eds.), Social diactology: In honour of Peter Trudgill, 16, 59-57. Amesterdam. John Benjamins.

14.Al-Wer, E. (2007). The formation of the dialect of Amman. In C. Miller, E.Al-Wer, D. Caubet\& J. Watson (Eds.), Arabic in the City: Issues in Dialect Contact and Language Variation, 55-76. London: Routledge.

15.El-Salman, M. (2003). Phonological and morphological variation in the speech of Fallahis 
in Karak (Jordan) (Unpublished doctoral dissertation). University of Durhan, UK.

16.Ferguson, C. (1959). Diglossia. Word, 15, 325340.

17.Haeri, N. (1987). Male/ Female Differences in Speech: An alternative interpretation. In K.Denning, S. Inkelas, F.McNair-Knox \& J. Richford (Eds.), Variation in language: Proceedings of the fifth annual conference of new ways of analyzing variation, 173-182. Stanford, CA: Stanford University.

18.Herin, B. (2013). Do Jordanians really speak like Palestinians ? Journal of Arabic and Islamic Studies, 13, 99-114.

19.Irsheid, O. (1984). The phonology of Arabic: Bani Hassan, a Bedouin Jordanian dialect ( Unpublished doctoral diss.). University of Illinois at Urbana-Champaign.

20.Khalil, A, M. (2010). A contrastive Grammar of English and Arabic, Amman: Jordan Book Center.

21.Miller, C. (2007). Arabic urban vernaculars: Development and changes. Arabic in the City. Hal archives, Routledge/ Taylor, France.

22.Mohammad, A. \& Al-Harahsheh, A. (2014). Language and gender differences in Jordanian spoken Arabic: A Sociolinguistics perspectives. Theory and Practice in Language Studies, 4 (5), 872-882. 
23.Omari, O \&Herk, G.V. (2016). A Sociophonetic Study of Interdental Variation in Spoken Arabic. Jordan Journal of Modern Languages and Literature, 8 (2), 117-137.

24.Saidat, A. M. (2010). Language Attitude: The case of Jordan. International Journal of Academic Research, 2 (6), 235-243.

25.Sakarna, A.K. (2005). The linguistic status of the Modern Jordanian Dialects. Arabica: Journal of Arabic and Islamic Studies, 52 (4), 522-543.

26.Zuraiq, W. \& Abu-Joudeh, M. (2013). Consonantal assimilation in four dialects of Jordanian Arabic. Studies in literature and language, 6 (2), 73-80. 


\section{List of Phonetic Symbols}

Below are the phonetic symbols used in transcribing the Arabic examples. It has to be noted that I have not changed the symbols when quoting from previous literature by other authors.

\begin{tabular}{|c|c|c|}
\hline $\begin{array}{l}\text { Arabic } \\
\text { letter }\end{array}$ & $\begin{array}{l}\text { IPA } \\
\text { symbol }\end{array}$ & Sound Description \\
\hline أ & ? & Voiced glottal plosive \\
\hline ب ب & $\mathrm{b}$ & Voiced bilabial plosive \\
\hline$ت$ & $\mathrm{t}$ & $\begin{array}{l}\text { Voiceless dento-alveolar } \\
\text { plosive }\end{array}$ \\
\hline$\dot{\Delta}$ & $\theta$ & $\begin{array}{l}\text { Voiceless interdental } \\
\text { fricative }\end{array}$ \\
\hline ج & $d_{3}$ & $\begin{array}{l}\text { Voiced post-alveolar } \\
\text { fricative }\end{array}$ \\
\hline$\tau$ & $\hbar$ & $\begin{array}{l}\text { Voiceless pharyngeal } \\
\text { fricative }\end{array}$ \\
\hline$\dot{\tau}$ & $\mathrm{x}$ & Voiceless velar fricative \\
\hline د & $\mathrm{d}$ & $\begin{array}{l}\text { Voiced dento-alveolar } \\
\text { plosive }\end{array}$ \\
\hline$\dot{j}$ & ð & Voiced interdental fricative \\
\hline $\mathrm{J}$ & $\mathrm{r}$ & Voiced alveolar trill \\
\hline j & $\mathrm{Z}$ & Voiced alveolar fricative \\
\hline س ( - ن & $\mathrm{s}$ & Voiceless dental fricative \\
\hline ش & $\int$ & $\begin{array}{l}\text { Voiceless alveo-palatal } \\
\text { fricative }\end{array}$ \\
\hline ص ص ص & $\mathrm{s}^{\mathrm{S}}$ & $\begin{array}{l}\text { Voiceless } \\
\text { velarised/emphatic alveolar } \\
\text { fricative }\end{array}$ \\
\hline 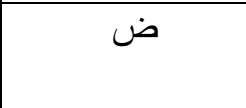 & $d^{\text {S }}$ & $\begin{array}{l}\text { Voiced velarised/emphatic } \\
\text { dento-alveolar plosive }\end{array}$ \\
\hline
\end{tabular}




\begin{tabular}{|c|c|c|}
\hline b & $\mathrm{t}^{\mathrm{f}}$ & $\begin{array}{l}\text { Voiceless } \\
\text { velarised/emphatic dento-alveolar } \\
\text { plosive }\end{array}$ \\
\hline ظ & $\partial^{\varsigma}$ & $\begin{array}{l}\text { Voiced velarised/emphatic } \\
\text { interdental fricative }\end{array}$ \\
\hline$\varepsilon$ & 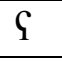 & Voiced pharyngeal fricative \\
\hline$\dot{\varepsilon}$ & $\gamma$ & Voiced velar fricative \\
\hline ف & $\mathrm{f}$ & $\begin{array}{l}\text { Voiceless labio-dental } \\
\text { fricative }\end{array}$ \\
\hline ق & $\mathrm{q}$ & Voiceless uvular plosive \\
\hline ك & $\mathrm{k}$ & Voiceless velar plosive \\
\hline J & 1 & Voiced dental lateral \\
\hline ? & $\mathrm{m}$ & Voiced bilabial nasal \\
\hline ن & $\mathrm{n}$ & Voiced alveolar nasal \\
\hline o & $\mathrm{h}$ & Voiceless glottal fricative \\
\hline 9 & $\mathrm{w}$ & Voiced labio-velar glide \\
\hline ي & $\mathrm{j}$ & Voiced palatal glide \\
\hline
\end{tabular}

For the emphatic or dark lateral, the symbol [1] is used. Arabic vowels:

\begin{tabular}{||c|c||}
\hline Short vowels & Long vowels \\
\hline \hline $\begin{array}{c}\text { afatha (short low central } \\
\text { vowel) }\end{array}$ & $\overline{\mathrm{a}}$ (long central low vowel) \\
$\begin{array}{c}\mathrm{u} \mathrm{\jmath}^{\complement} \text { amma (short back } \\
\text { mid-low vowel) }\end{array}$ & $\overline{\mathrm{u}}$ (long back high vowel) \\
\hline $\begin{array}{c}\text { ikasra (short front kid- } \\
\text { high vowel) }\end{array}$ & $\overline{\mathrm{1}}$ (long front high vowel) \\
$\begin{array}{c}\text { The symbol / o / is used as } \\
\text { a variant of [u]. It is a long mid } \\
\text { vowel }\end{array}$ & $\overline{\mathrm{e}}$ (Diphthong) \\
\end{tabular}


